
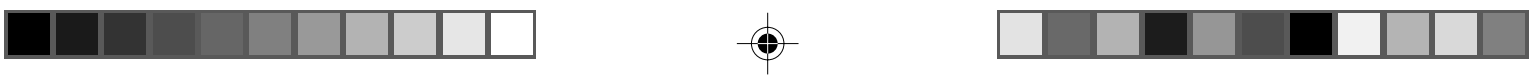

\title{
NÅR KULTUR KOMMER I VEJEN \\ Kapitalmøder og kulturforståelser på en international uddannelse i Danmark ${ }^{1}$
}

\section{LISANNE WILKEN}

Gennem de seneste 10-15 år er der kommet flere udenlandske studerende på de videregående uddannelser i Danmark. En stor del af dem er udvekslingsstuderende, der tilbringer et semester eller to ved et dansk universitet, men der er også et stigende antal udenlandske studerende, der indskrives på almindelige vilkår. Den $\emptyset$ gede studentermobilitet kan betragtes som en slags globaliseringsproces (se fx Singh \& Doherty 2004), men den kan også ses som del af integrationsprocesserne i Europa. Studentermobilitet kan kædes til en række vigtige europæiske kulturpolitikker, som har til formål at øge mobiliteten i Europa og skabe mere interkulturel interaktion (http://ec.europa.eu/culture/eac/dialogue/year2008/ year2008_en.html).

De mobile studerende er blevet vigtige for de nationale universiteter. For mange af dem udgør udenlandske studerende en direkte eller indirekte $\varnothing$ konomisk indtægtskilde (Vickers \& Bekhradnia 2007), hvilket betyder, at universiteterne har en interesse i at tiltrække dem. De fleste betragter tilgangen af udenlandske studerende som en form for anerkendelse (Ollikainen 1996). Med begreber lånt fra den franske sociolog Pierre Bourdieu kunne man sige, at mobile studerende er blevet en del af kampen om symbolsk og økonomisk kapital blandt universiteter - nationalt, i Europa og internationalt.

Men kampen om de mobile studerende er ulige. Meget tyder på, at mobile studerende foretrækker engelsksprogede lande og universiteter (Singh \& Doherty 2004:10). I 2002 var $42 \%$ af alle udenlandske studerende således indskrevet ved universiteter i Storbritannien og USA (Naidoo 2005). Så selv om Europa er ved at udvikle sig til et særligt marked for uddannelser på grund af Bolognaprocessen og Sokratesprogrammerne (Teichler 2004; Luiten-Lub et al. 2005), gør særlige forhold sig gældende for universiteter, hvor det primære undervisningssprog ikke er engelsk. For at være med i kampen om de udenlandske studerende må disse universiteter udbyde flere kurser og uddannelser på engelsk. Og 
noget tyder på, at de også må tilføje uddannelserne en merværdi. Ser man eksempelvis på hjemmesider og brochurer for engelsksprogede kandidatuddannelser i Danmark, vil man opdage, at de næsten alle averterer med, at de har mere at byde på end blot en engelsksproget uddannelse. Det kan være særlige pædagogiske metoder, særlige forskningsmiljøer, særlige tværfaglige kombinationer eller bare international erfaring, interkulturelle kompetencer og mulighed for at opbygge internationale netværk (se også Baumgratz \& Shaw 1993:332; Teichler 2004:4067). Hvor man på engelsksprogede universiteter fors øger at integrere de udenlandske studerende i nationale uddannelsesforløb med de problemer, det måtte indebære (se fx Caroll \& Ryan 2005), skaber man i lande som Danmark internationale studiemiljøer, hvor det internationale er en del af attraktionen.

Internationaliseringen af universitetsuddannelser er baseret på to præmisser. Den ene er, at det, Bourdieu og Passeron (1979) har kaldt 'skolastisk kapital', forholdsvis uproblematisk kan flyttes fra en national uddannelsessammenhæng til en anden. Den anden er, at det er muligt at skabe uddannelsesmiljøer, hvor forskel er en fordel, og hvor alle kan bidrage konstruktivt. Begge præmisser er interessante i forhold til diskussioner om kulturmøder, fordi de indebærer en idé om interkulturel kompatibilitet inden for de videregående uddannelser.

I denne artikel vil jeg diskutere disse præmisser i forhold til en undersøgelse, jeg har foretaget på en international uddannelse i Danmark. Jeg vil først diskutere nogle af de problemer, der kan være involveret i anerkendelsen af 'udenlandsk' skolastisk kapital. Dernæst vil jeg diskutere, hvordan kulturforskelle opfattes og sættes i spil i et internationalt studiemiljø. Artiklen indledes med en introduktion til det internationale uddannelsessted, hvor jeg har foretaget min undersøgelse, samt en kort diskussion af undersøgelsens præmisser og metoder. Herefter følger et afsnit, hvor jeg giver mit bud på, hvordan man kan forholde sig til kulturmøder i denne sammenhæng. Dernæst fremlægger jeg nogle af undersøgelsens resultater, og til sidst diskuterer jeg, hvordan studerende i et internationalt studiemiljø oplever kultur og kulturmøder.

\section{Baggrunden}

Artiklen er baseret på en undersøgelse, jeg har foretaget på Europastudier på Århus Universitet. ${ }^{2}$ Europastudier er et tværfagligt områdestudium på Det Humanistiske Fakultet. Uddannelsen blev grundlagt i 1991 som en af de første fuldt engelsksprogede tilvalgsuddannelser på fakultetet. Siden 1999 har uddannelsen bestået af en etårig suppleringsuddannelse og en toårig kandidatuddannelse. Ud fra en antagelse om, at et internationalt studiemiljø kan give de studerende praktisk erfaring med internationalt og interkulturelt samarbejde (http://www.iho.au.dk/ 

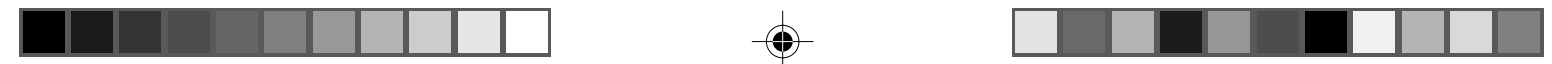

en/es/studies/intro), gør man på uddannelsen en indsats for at tiltrække udenlandske studerende, ligesom man arbejder med pædagogiske metoder, der fremmer og tematiserer internationalt og interkulturelt samarbejde (ibid.).

Suppleringsuddannelsen har fra starten haft en forholdsvis høj andel af udenlandske studerende (mellem 50 og $60 \%$ på mange af uddannelsens kurser), fordi den fungerer som udbud for de mange udvekslingsstuderende, der kommer til Århus Universitet for et eller to semestre, og som er afhængige af kursusudbud på engelsk. Kandidatuddannelsen har først for alvor haft tilgang af udenlandske studerende i dette århundrede. Siden 2004 har andelen af udenlandske studerende udgjort omkring halvdelen af optaget.

Fordelingen af nationaliteter er forskellig på suppleringsuddannelsen og kandidatuddannelsen. På suppleringsuddannelsen finder man et bredt udsnit af studerende fra EU og EØS og fra de mange ikke-europæiske lande, som universitetet har udvekslingsaftaler med. På kandidatuddannelsen kommer de fleste studerende fra Danmark, Østeuropa og Kina, ${ }^{3}$ mens kun en mindre del kommer fra Vesteuropa eller fra andre lande. Til forskel fra suppleringsuddannelsen, hvor udenlandske studerende typisk kun tager et eller to af uddannelsens kurser, er danske og udenlandske studerende på kandidatuddannelsen indskrevet på samme vilkår; de følger det samme uddannelsesforløb, har teoretisk set de samme rettigheder og ender med samme universitetsgrad.

Undersøgelsen har afsæt i en selvinitieret intern undersøgelse på Europastudier i 2004. Anledningen var en erkendelse af, at der både blandt ansatte og (danske) studerende havde udviklet sig en slags dobbeltdiskurs om internationalisering. På den ene side var det med stor begejstring, at både det internationale og det engelsksprogede aspekt af uddannelsen blev fremhævet, når uddannelsen blev omtalt udadtil. Det var, som en dansk studerende udtrykte det, ,lidt blæret at være tilknyttet et internationalt, engelsksproget studiemiljø i Danmark“ (Md2). ${ }^{4}$ På den anden side blev der internt brugt megen energi på at diskutere problemer: Trods 'det blærede' ved at tage en international uddannelse havde de danske og udenlandske studerende ikke særlig meget med hinanden at gøre, de internationale og interkulturelle læsegrupper, der blev nedsat, fungerede ofte ikke, og det var svært at engagere de studerende i miljøet omkring uddannelsen.

For at kunne forbedre forholdene iværksatte studienævnet tidligt i 2004 en spørgeskemaundersøgelse blandt studerende og ansatte, som skulle afdække fordele og frustrationer ved at tage en uddannelse i et internationalt miljø. ${ }^{5}$ Spørgeskemaundersøgelsen blev fulgt op af en række interviews med studerende. Unders $\varnothing$ gelsen afslørede nogle mønstre og problemstillinger, som ikke var forudset, men som var værd at unders $\emptyset$ ge nærmere. Eksempelvis var der noget, der tydede på, at de studerende valgte uddannelsen af andre årsager, end man havde forven- 

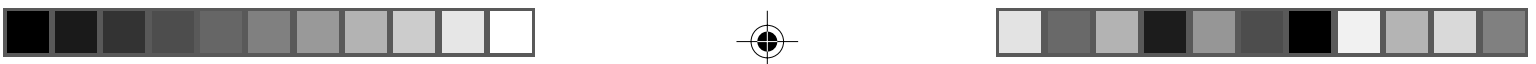

tet. I spørgeskemaundersøgelsen havde kun et fåtal angivet, at de havde valgt uddannelsen, fordi de var interesserede i Europa, eller fordi de gerne ville studere $i$ et internationalt miljø. Langt flere svarede, at de havde valgt Europastudier, „fordi min kæreste er dansk, og jeg ikke kunne finde andre engelsksprogede uddannelser“ ${ }^{6}$ eller ,fordi jeg dumpede til adgangsprøven til universitetet i mit hjemland, men er nødt til at have en uddannelse“ eller „fordi jeg blev afvist på $\emptyset$ konomiuddannelsen“. Noget kunne således tyde på, at valget af Europastudier ikke bare handler om Europastudier. Dette understøttes også af svarene på spørgsmålet om, hvorfor de studerende havde valgt en international uddannelse. Disse lød ofte: „Det har jeg ikke tænkt over“, eller „hvad mener I egentlig med international?".

Data fra spørgeskemaerne og de efterfølgende interviews gjorde det muligt at identificere fire årsager til, at studerende vælger uddannelsen. En mindre gruppe (både danske og udenlandske) vælger uddannelsen, fordi de er interesseret $\mathrm{i}$ Europa, og/eller fordi de er tiltrukket af det internationale studiemiljø. En større gruppe, fortrinsvis danske studerende, forklarer deres valg af Europastudier med henvisning til en eller anden form for utilfredshed med deres grunduddannelse. Resten af de (udenlandske) studerende kan opdeles i dem, der har valgt Europastudier, fordi de af andre grunde er i Århus og „,det er på engelsk“, og dem, der har valgt studiet, fordi de forventer at forbedre deres karrieremuligheder hjemme. ${ }^{7}$ På den baggrund besluttede jeg at lave en ny undersøgelse, som mere specifikt havde til formål at afdække forskelle og ligheder i studentergruppen for blandt andet at unders $\varnothing \mathrm{ge}$, hvordan disse forskelle blev tillagt betydning af studerende og undervisere. Det er resultaterne fra denne undersøgelse, jeg trækker på i denne artikel.

\section{Præmisser og metoder}

Den undersøgelse, der præsenteres på de følgende sider, har jeg foretaget som ansat på Europastudier. Det har en række implikationer både for materialeindsamlingen og for præsentationen af data. I dette afsnit vil jeg diskutere et par af dem.

Som ansat på Europastudier står jeg i en helt bestemt relation til såvel studerende (jeg er underviser og bedømmer) som til de øvrige ansatte (jeg er kollega), og det har betydning både for, hvilke data jeg kan indsamle, og hvilke data jeg kan fremlægge. I forhold til de studerende, som især er i fokus i denne artikel, har det, at jeg er underviser og bedømmer, mindst tre forskellige implikationer. Til en start har det den indlysende implikation, at der er grænser for, hvilke overvejelser og informationer de studerende deler med mig. Der er også grænser for, i hvilke 

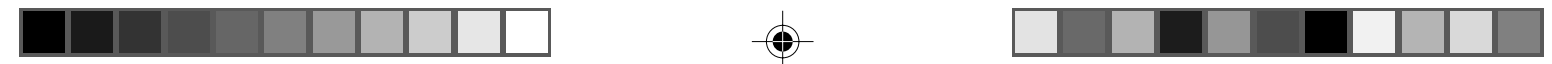

kontekster jeg kan indsamle data. Jeg hænger ikke ud med de studerende, jeg omgås dem ikke privat, og jeg taler heller ikke med dem om ret mange andre ting end dem, der på en eller anden led har relation til uddannelsen. En anden implikation er, at de studerende sandsynligvis udtaler sig mere reflekteret om kultur, kulturforskelle og kulturforskelles betydning i interviewsituationen, end de måske gør i andre situationer. I næsten alle de interviews, jeg har foretaget, har de studerende været meget bevidste om, hvilket kultursyn jeg repræsenterer, og de har både direkte og indirekte forholdt deres egne udtalelser til min kulturforståelse. Pierre Bourdieu har i flere af sine værker diskuteret relationen mellem forsker og informanter og i den forbindelse bemærket, at der kan opstå en slags konkurrencesituation, hvor informanterne ikke bare informerer forskeren, men også konkurrerer med hende om at udlægge data (se fx Bourdieu 2003). Informanterne bliver det, Bourdieu har kaldt 'spontanteoretikere' på deres egen praksis (Bourdieu 1990:21-2). I forbindelse med min undersøgelse har dette navnlig givet sig udslag $\mathrm{i}$, at de studerende også har brugt interviewsituationen til at imponere mig og udfordre mig. En tredje implikation er, at jeg har en praktisk viden om, hvad der foregår, ikke bare 'frontstage', men også 'backstage' (Goffman 1959) på Europastudier og på Århus Universitet. Og selv om en række 'backstage'-informationer nødvendigvis må behandles fortroligt, spiller de en rolle for min analyse. Endelig spiller det en rolle, at jeg har en professionel interesse i Europastudier. Der er ikke bare tale om en akademisk interesse for en interessant problemstilling, men en investeret interesse $\mathrm{i}$ at forstå, hvilken rolle kultur spiller for undervisningen og for interaktionen på stedet.

Undersøgelsen, som har strakt sig over fire år (2004-2007), har på en eller anden led involveret alle studerende og ansatte, der har været tilknyttet Europastudier i denne periode. Materialeindsamlingen har bestået i observationer i og uden for undervisningslokalerne, small-talk med studerende og undervisere, diskussion med undervisere, sekretærer og administratorer samt strukturerede og semistrukturerede interviews med 30 studerende. Herudover har jeg foretaget en forholdsvis systematisk kortlægning af de sociale, kulturelle og økonomiske variabler, der kunne antages at have betydning for de studerendes studievalg, for deres præstationer og for deres forståelse af uddannelsens interkulturelle dimension. Jeg har således indhentet information om de studerendes baggrund, om deres forældres uddannelse og erhverv, om deres sprogkundskaber, rejsevaner, migrationshistorier og om deres 'kulturelle ballast', når det gælder kendskab til danske og europæiske forhold, til kunst og kultur, til videnskab og filosofi og til den slags banal viden, som kan lette dagligdagen på en dansk/århusiansk uddannelsesinstitution. Denne information er først og fremmest indsamlet ved hjælp af et meget omfattende spørgeskema. I undersøgelsesperioden har jeg indsamlet 160 

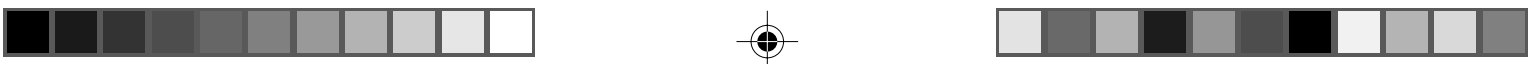

spørgeskemaer. ${ }^{8}$ Analysearbejdet er stadig i sin vorden, og nærværende artikel repræsenterer først og fremmest et forsøg på at finde mulige angrebsvinkler. I de næste par afsnit præsenterer jeg med reference til eksempler fra mit empiriske materiale nogle af de analytiske overvejelser, jeg indtil videre har gjort mig.

\section{Kapitalmøder}

Internationale uddannelsesmiljøer har længe figureret $\mathrm{i}$ litteraturen om kulturmøder og interkulturel interaktion (se fx Hofstede 1986; Baumgaratz \& Shaw 1993; Otten 2003). Dette skyldes sandsynligvis, at det forekommer oplagt at antage, at internationale uddannelsesmiljøer pr. definition er flerkulturelle og derfor rammer om møder og interaktioner mellem mennesker fra forskellige kulturer (se Volet \& Ang 1998). Det skyldes måske også, at internationale uddannelsesmiljøer ofte skilter med, at en del af attraktionen er mødet med mennesker fra andre kulturer og muligheden for at udvikle interkulturelle kompetencer. Som Knight og De Wit eksempelvis har fremhævet, er en af de store fordele ved internationalisering af uddannelsesmiljøer, at de studerende får mulighed for ,at fungere i internationale og interkulturelle kontekster“ (Knight \& De Wit 1995:13).

Men selv om internationale miljøer ofte automatisk klassificeres som rammer om kulturmøder, er forskere ikke enige om, hvordan de kulturer, der mødes, skal defineres. De er heller ikke enige om, hvilken rolle kultur spiller for mødet og for interaktionen mellem forskellige mennesker. Der findes en lang række teorier om kultur og om interaktion, som giver anledning til forskellige forståelser af kulturmødets anatomi (se fx Christensen 1994). Min egen undersøgelse har med inspiration fra Bourdieu og Bourdieu-inspireret forskning fokuseret på de studerendes kulturelle ressourcer og på deres muligheder for at få dem anerkendt som kapital inden for rammerne af et internationalt uddannelsessted. I den forstand interesserer jeg mig for kulturmøder som møder mellem mennesker, der ikke bare har forskellige mængder og sammensætninger af kapital i Bourdieu'sk forstand, men som også har akkumuleret deres kapitaler i forskellige, men parallelle sammenhænge. I det følgende indkredser jeg kapitalbegrebet lidt nærmere.

\section{Kulturel kapital}

I artiklen „The Forms of Capital“ definerer Bourdieu kapital som ,akkumuleret arbejde“ (Bourdieu 1986:241), og i Distinction præciserer han det som „samlingen af faktiske og omsættelige ressourcer og kapaciteter“ (Bourdieu 1984:114). 'Kapital' hos Bourdieu er ikke kun økonomiske, men også sociale og kulturelle 

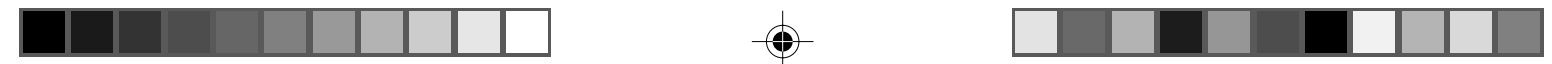

ressourcer, som i bestemte sammenhænge og under visse forudsætninger kan 'omveksles' til status, anerkendelse og indflydelse og til andre former for kapital. I uddannelsessystemet er det især kulturel kapital, der er i spil, både som den kapital, det gælder om at have, og som den kapital, det gælder om at tilegne sig.

I sit arbejde med kulturel kapital skelner Bourdieu mellem tre forskellige aspekter af den: objektiveret, inkorporeret og institutionaliseret kulturel kapital. Objektiveret kulturel kapital refererer til kulturrelaterede objekter og udtryk - fx bøger, malerier, musikinstrumenter, møbler, tøj og ipods. Disse objekter og udtryk klassificeres som god og dårlig smag, som udtryk for større eller mindre æstetisk sans. Ifølge Bourdieu er det vigtigt at være opmærksom på, at denne klassifikation er en social konstruktion, som er relateret til de andre aspekter af den kulturelle kapital. Inkorporeret kapital er den, man tilegner sig gennem socialisering $\mathrm{i}$ familien. Her udvikler man som del af habitus dispositioner for at sætte pris på bestemte kulturelle udtryksformer, ligesom man tilegner sig sprogbrug, manerer og omgangsformer. Ifølge Bourdieu (og andre) er der sociale forskelle på, hvilke dispositioner man udvikler, hvilket betyder, at børn, der vokser op i det samme samfund, har socialt forskellige dispositioner for at tilegne sig nye kulturelle kapitaler. Æstetisk sans og smag er på denne måde socialt afledte dispositioner, som man inkorporerer, og ikke naturlige dispositioner, som man har. Institutionaliseret kulturel kapital er den kapital, der forvaltes, forrentes og formidles i samfundets kulturformidlende institutioner, især i uddannelsessystemet. I moderne meritokratiske samfund er det uddannelsessystemet, der er ansvarligt for at gøre samfundets kulturelle kapital tilgængelig for alle uanset social herkomst (Bourdieu 1984, 1986).

En af Bourdieus fortjenester var, at han viste, at ideen om lige adgang til uddannelsessystemets kulturelle kapitaler er en illusion. For det første, fordi uddannelsessystemets kapital ikke er neutral. Tværtimod er uddannelsessystemets kapital identisk med den kapital, de dominerende klasser allerede besidder. For det andet, fordi børn allerede har udviklet bestemte dispositioner (habitus) for at tilegne sig kapital, når de starter i skole. Uddannelsessystemet er således dobbelt diskriminerende over for bestemte sociale grupper, og når det overhovedet kan lade sig gøre i samfund, som faktisk hylder ideen om lige adgang til uddannelse og til social mobilitet, så skyldes det først og fremmest, at man forveksler socialt udviklede dispositioner med talent og evner og derfor opretholder en forestilling om, at privilegier i moderne, demokratiske samfund tildeles efter fortjeneste og i forhold til objektive kriterier.

Bourdieus begreb om kulturel kapital er udviklet $i$ en national sammenhæng, hvor det først og fremmest er blevet brugt til at dokumentere og diskutere den sociale distribution af kulturel kapital og den deraf følgende institutionaliserede reproduktion af social ulighed. Dette er også interessant i en international uddan- 

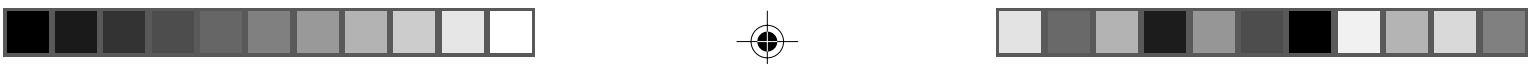

nelsessammenhæng, men her er det tillige interessant at forholde sig til betydningen af nationale (og regionale) variationer over kulturel kapital. Uddannelsessystemets kulturelle kapital er ikke nødvendigvis 'bare' udtryk for bestemte klassedispositioner. Som jeg vender tilbage til, er den er muligvis også lokalt forankret, forstået på den måde, at den er bundet op på specifikke eksempler, konstrueret fra særlige vinkler og formidlet i forhold til en lokalt forankret kontekstviden.

Grundlæggende betyder det, at selv hvis studerende i en international sammenhæng kommer fra nogenlunde de samme sociale klasser og derfor muligvis har nogenlunde samme mængde og slags kulturel kapital, har denne kapital ikke nødvendigvis den samme form. Spanske, tyrkiske, kinesiske og rumænske studerende kan således have tilegnet sig den samme formelle viden, som danske studerende har. Men de perspektiver, de har på denne viden, de eksempler, de forstår og formidler den i forhold til, og de konsekvenser, de drager af den, er muligvis meget forskellige fra deres danske kollegaers. Derfor kan man ikke uden videre gå ud fra, at de studerende er i stand til at genkende og anerkende hinandens kapitaler. Min undersøgelse handler ikke om, hvordan de studerende formelt klarer sig, men om hvordan de forholder sig til hinanden, blandt andet i forhold til, hvem de mener bidrager konstruktivt til undervisningssituationer og til samarbejde. I den forstand handler den om, i hvilket omfang de studerende genkender og anerkender hinandens kapitaler.

I det følgende vil jeg fremlægge og diskutere et par af undersøgelsens resultater. Jeg starter med at se nærmere på de studerendes baggrund. Dernæst diskuterer jeg deres studierelevante viden. Endelig undersøger jeg, i hvilket omfang og på hvilke præmisser de studerende anerkender og genkender hinandens kapitaler.

\section{Familiehistorier}

I et af sine tidligste arbejder med kulturel kapital hævdede Bourdieu (1974:327), at kulturel kapital kan måles gennem indsamling af data om det sted, man vokser op, om forældres og bedsteforældres uddannelser og om, hvor ofte man deltager i hvilke kulturelle aktiviteter. I interviewguiden fra Distinction spørges desuden til en række andre forhold, der angår livsstil, økonomi og forbrug. Derfor har jeg i min undersøgelse indsamlet data om, hvor de studerende er vokset op, hvilke uddannelser og arbejde deres forældre og bedsteforældre har (haft), om deres kulturforbrug samt om deres forældres $ø$ konomiske og kulturelle kapitaler. Det sidste betyder, at de studerende er blevet spurgt om, hvorvidt deres forældre ejer fast ejendom, original kunst, aktier og biler, hvor de er født og opvokset, om de er flyttet meget, har levet i flere lande eller har rejst meget. Denne del af unders $\varnothing$ gelsen har til formål at kortlægge, hvilke potentielt betydningsfulde forskelle der er 

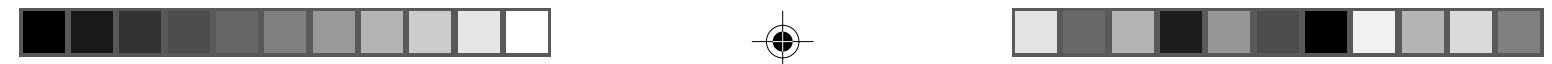

mellem de studerende i forhold til sociale klasser og nationalitet. De indsamlede data er blevet analyseret på forskellige måder. Først er alle data for samtlige studerende blevet analyseret; dernæst er data for nationale og regionale grupper blevet analyseret, i det omfang det har været muligt. Disse analyser har identificeret en række potentielt interessante mønstre af forskelle og ligheder mellem de studerende både inden for og på tværs af nationale og regionale grupperinger, hvoraf jeg her blot skal nævne nogle stykker.

Et af de forhold, min undersøgelse har afdækket, er, at forholdsvis mange af de studerende på Europastudier er førstegenerationsstuderende eller det, Bourdieu (1988) har kaldt ,,de heldige overlevende“, dvs. studerende, som klarer sig i uddannelsessystemet, på trods af at de ikke har en akademisk ballast. Data for samtlige studerende viser, at $43 \%$ kommer fra hjem, hvor ingen af forældrene har studentereksamen eller anden videregående uddannelse. Data viser desuden, at kun 27 $\%$ af de studerendes bedsteforældre har studentereksamen eller anden videregående uddannelse, hvilket betyder, at studentergruppen som helhed har forholdsvis kort tradition for videregående uddannelse.

Førstegenerationsstuderende findes især blandt danske, østeuropæiske ${ }^{9}$ og ikke-europæiske, ikke-vestlige studerende. ${ }^{10}$ For de danske studerendes vedkommende gælder, at kun $7 \%$ af bedsteforældregenerationen og $20 \%$ af forældregenerationen har studentereksamen eller videregående uddannelse. I praksis betyder det, at ca. $82 \%$ af de danske studerende er førstegenerationsstuderende. Der er en mindre gruppe danske studerende, hvis forældre er kunstnere, men hvis bedsteforældre havde studentereksamen eller anden videregående uddannelse. Også de afrikanske og kinesiske studerende, der læser på Europastudier, er overvejende førstegenerationsstuderende, mens tallet for østeuropæiske studerende er lidt lavere. For de østeuropæiske studerende gælder det $\mathrm{i} \emptyset v$ vrigt, at en del af de forældre, der har en videregående uddannelse, ikke arbejder inden for deres fag, enten fordi de tilhører politiske, etniske eller religiøse mindretal, som har haft vanskeligt ved at få relevant arbejde, eller fordi de er migreret til andre lande og arbejder som ufaglærte - eller begge dele. Flertallet af de vesteuropæiske/vestlige studerendes forældre har en videregående uddannelse. Flertallet af disse har en ikke-humanistisk baggrund, men der er også en del, der har en samfundsfaglig (sociologisk) baggrund eller er lærere.

Data om familiebaggrund (herunder data om familiernes karriereforhold og $\varnothing$ konomiske forhold ${ }^{11}$ ) viser, at de studerende kommer fra meget forskellige sociale miljøer. Man kan identificere fire-fem forskellige grupper afhængigt af, hvad man præcis lægger vægt på. Ingen af disse grupper følger nationale eller regionale linjer, men der er en tendens til, at flertallet af de studerende fra bestemte nationaliteter eller regioner falder i den ene eller den anden gruppe: Flertallet af de danske 
og de østeuropæiske studerende er førstegenerationsstuderende, flertallet af de vestlige studerende har veluddannede forældre etc. Grundlæggende betyder det, at det er muligt at forveksle det sociale med det nationale eller regionale. Og det er vigtigt at være opmærksom på i en sammenhæng, hvor folk især klassificeres i forhold til nationale og regionale tilhørsforhold.

Jeg har også set på de studerendes egen uddannelsesbaggrund. Her gør nogle andre mønstre sig gældende. Næsten alle danske og næsten alle kinesiske studerende har en humanistisk baggrund, mens næsten alle østeuropæiske studerende har en samfundsvidenskabelig baggrund. De øvrige studerende fordeler sig nogenlunde ligeligt mellem samfundsvidenskabelige og humanistiske baggrunde, uden at der tegner sig noget mønster. Samtidig gælder det, at mange af de østeuropæiske førstegenerationsstuderende allerede har gennemført en kandidateksamen, når de starter på Europastudier. På hver årgang sidder der således et par østeuropæiske jurister eller politologer, som håber på at forbedre deres karrieremuligheder hjemme ved at tage endnu en uddannelse i Vesteuropa.

I næste afsnit vil jeg diskutere, hvordan og i hvilket omfang disse forskelle afspejler sig i de studerendes studierelevante viden og ressourcer.

\section{Hvis viden er kapital}

Mit arbejde med kulturel kapital er et work in progress. Med inspiration både fra Bourdieus eget arbejde med kulturel kapital og fra andre forskeres arbejde med begrebet (fx Lamont \& Lareau 1988; Broady 2001; Blackledge 2001; Lareau \& Weininger 2003; m.fl.) har jeg indsamlet mængder af data om de studerendes forbrugsvaner samt om deres viden og knowhow, som potentielt kunne være kulturel kapital. I det følgende skal jeg især forholde mig til to typer data, der kan være relevante for at vurdere kulturel kapital i forhold til den konkrete kontekst, nemlig de studerendes viden om europæiske politiske forhold og de studerendes viden om kultur. Disse data er naturligvis langtfra udtømmende, når man skal vurdere de studerendes kapitaler, men de er relevante, fordi denne form for viden både spiller en rolle for de studerendes præstationer i undervisningen og for, hvad de har at byde ind med i det interkulturelle samarbejde.

Viden om europaiske forhold

Det forekommer rimeligt at antage, at studierelevant viden potentielt er kapital. Med studierelevant viden refereres til viden om historiske, politiske og sociale forhold i Europa samt til viden om samfunds- og kulturvidenskabelig teori. Denne viden er dels en forudsætning for at klare sig på uddannelsen og dels en forudsætning for at kunne bidrage til diskussioner og samarbejde. 

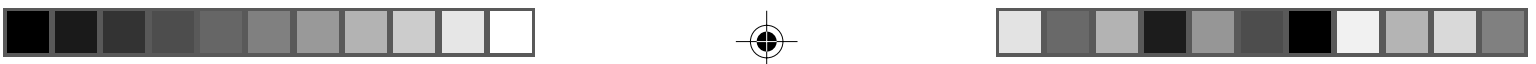

Min undersøgelse viser, at der er et vist sammenfald mellem de studerendes familiebaggrund og deres viden om historiske, politiske og sociale forhold i Europa. Studerende fra en veluddannet baggrund har generelt den største viden om europæiske forhold, men også studerende, der allerede har en kandidatuddannelse, og studerende med migrantbaggrund har forholdsvis stor viden inden for dette felt. Studerende fra familier uden tradition for uddannelse har generelt mindre studierelevant viden. Undersøgelsen viser imidlertid også, at de studerendes viden om europæiske forhold i høj grad er orienteret mod de steder, de kommer fra. Bortset fra en meget lille tværnational gruppe, der i forhold til egen selvfremstilling måske bedst kan klassificeres som 'postkulturel', betyder det for det første, at de studerendes viden er betinget af lokale og nationale relevanskriterier, for det andet, at den i høj grad er bundet op på lokale, nationale og regionale eksempler, og for det tredje, at den stammer fra lokale og nationale kilder. På denne måde er der store forskelle både i mængden og i arten af de studerendes studierelevante viden. Det er ikke bare sådan, at nogle ved mere, og andre ved mindre. Det er også sådan, at noget viden er mere genkendelig end anden viden. Det betyder, at man ikke bare kan gå ud fra, at dem med mest viden kommer til at fremstå som de mest vidende.

\section{Viden om kulturelle forhold}

Viden om kulturelle forhold angår i min unders $\varnothing$ gelse tre slags viden: ${ }^{12}$ viden om finkultur (malerier, litteratur, musik m.v.), viden om populærkultur (musik, tvudsendelser, film m.v.) samt viden om europæiske filosofiske og samfundsvidenskabelige tænkere. Disse tre slags viden er defineret i forhold til andre forskeres videreudvikling af Bourdieus begreb om kulturel kapital og i forhold til den form for kontekstviden, som er i spil på Europastudier, og som jeg har identificeret ved at observere egen ${ }^{13}$ og andres undervisning og ved at lytte til de studerende.

Hvad angår de to første typer viden, er der ikke umiddelbart den store forskel blandt de studerende. De har nogenlunde lige lidt kendskab til finkultur og nogenlunde lige meget kendskab til populærkultur. Forskellen findes først $\mathrm{og}$ fremmest i, hvordan de selv vurderer deres kendskab til finkultur og populærkultur, og i hvor 'bred en smag' (se fx van Eijck 2001) de ser ud til at have. Samtidig er der meget, der tyder på, at studerende, der kommer fra en veluddannet baggrund, har en langt større bredde i deres smag end studerende, hvis forældre ingen videregående uddannelse har. De studerendes kendskab til filosofiske og samfundsvidenskabelige tænkere bekræfter denne opdeling: Studerende med en veluddannet familiebaggrund har generelt en større referenceramme end andre studerende. Her bliver forskellen i de studerendes egen uddannelsesbaggrund dog også tydelig. Der er markant forskel på, hvilke filosofiske og samfundsvidenskabelige tænkere og strømninger studerende med henholdsvis humanistisk 

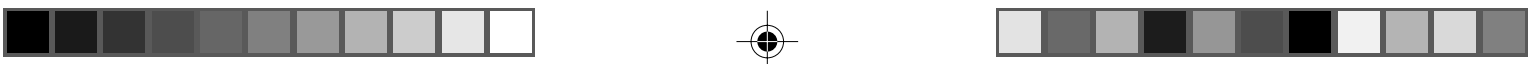

og samfundsvidenskabelig baggrund har kendskab til, ligesom der er regionale og nationale forskelle på de navne og de strømninger, de refererer til.

Når man vurderer de studerendes studierelevante viden - og i øvrigt også når man vurderer deres 'smag' i bredere forstand - er det muligt at identificere tre forskellige grupper: En gruppe, som i udgangspunktet har forholdsvis lidt studierelevant viden. Den består fortrinsvis af danske førstegenerationsstuderende, men også asiatiske og nogle af de østeuropæiske studerende lander her. En anden gruppe med forholdsvis meget viden om politiske og historiske forhold, der først og fremmest består af østeuropæiske studerende, men nogle enkelte vestlige studerende lander her. Og endelig en gruppe, der både har megen kulturel og megen politisk viden. Den består overvejende af vesteuropæiske/vestlige studerende, herunder enkelte danske studerende.

Som man kan se, er der en relativ korrespondance både mellem de studerendes nationale/regionale tilhørsforhold og uddannelsesniveauet i deres familie og mellem uddannelsesniveauet i deres familie og mængden af deres viden. Hermed kommer det til at se ud, som om nogle nationaliteter har en større referencerammer og mere 'kapital' end andre nationaliteter. Men det er ikke nødvendigvis tilfældet. Det kunne også forholde sig sådan, at forskellene skyldes andet end nationalitet. I næste afsnit vil jeg se nærmere på, hvordan fordelingen af potentielle kapitaler manifesterer sig i de studerendes interaktioner med hinanden.

\section{Kapital i kontekst}

Som Bourdieu har gjort opmærksom på, er kulturel kapital en kulturspecifik kompetence, der kan omsættes til en ressource i bestemte sociale sammenhænge (Bourdieu 1986:241). Ovenfor har jeg kort skitseret nogle potentielle kapitaler, men i praksis skal de genkendes for at blive anerkendt som kapital. Derfor er det ikke kun relevant at se på, hvor megen eller hvor lidt viden hvilke studerende har, men også at forholde sig til deres muligheder for at få deres viden genkendt. Viden er nemlig ikke neutral. Og for at få viden anerkendt som viden - ikke bare i en opgave, men i uddannelsessammenhængen som helhed - kræver det, at man kan formulere den på en måde, så den genkendes som legitim viden. Et problem i denne forbindelse er, at de studerendes viden er præget af deres nationale og regionale baggrund på to forskellige måder. For det første er de studerendes viden bundet op på eksempler fra deres hjemlande. Dette gør det i sig selv vanskeligt at genkende viden som (relevant) viden, fordi de studerende forholder sig til de samme problemstillinger fra meget forskellige perspektiver. I en diskussion om EU's grænseproblematikker vil en dansk studerende således typisk mene, at spørgsmålet om Tyrkiet er vigtigst, mens en polsk studerende typisk vil fremhæve 

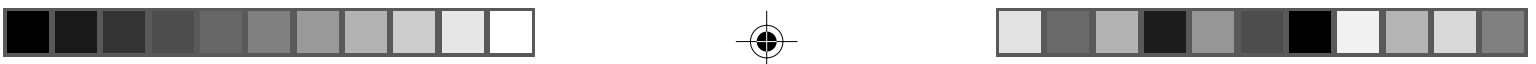

spørgsmålet om Rusland. Og bortset fra at det giver to forskellige diskussioner, betyder det også, at det kan være vanskeligt for de studerende at anerkende hinandens relevanskriterier. For det andet er der en tendens til, at de studerende forholder sig til det, andre studerende siger, ud fra nogle for-forståelser af, hvordan de andre er. I en lidt anden sammenhæng har Bourdieu bemærket, at når mennesker af forskellig nationalitet eller etnicitet taler sammen ,er det ikke to mennesker, der taler med hinanden "(Bourdieu 1993:82). Det er nutidige og historiske relationer mellem nationer, religioner og etniciteter, der taler. Det betyder, at forudfattede meninger om de andre og deres nationer - som er en del af deres inkorporerede viden om verden og virkeligheden - framer (Bateson 1991) opfattelsen af, hvad individuelle studerende repræsenterer. Imidlertid forholder det sig sådan, at mange studerende oplever, at de meninger, andre har om deres land, er baseret på forældet, forkert eller fordomsfuld viden.

\section{Kultursnak}

Studerende på Europastudier befinder sig i en kontekst, hvor forskelle mellem nationalstater hele tiden tematiseres. De fleste undervisningsforl $\varnothing b$ fokuserer på forskelle og ligheder, alliancer og uenigheder mellem de studerendes hjemlande. Det gælder, uanset om de studerende kommer fra Europa eller ej, fordi relationerne mellem Europa og resten af verden også tematiseres. Den konstante tematisering af nationalstater og ikke mindst af konflikter og uenigheder mellem stater bevirker ifølge flere studerende, at ,man bliver meget bevidst om sin nationale identitet“ (Fli2), og „man bliver ansvarliggjort for det, ens land gør“ (Mt1). Det betyder også, at ens land hele tiden er til fælles diskussion, og at man konfronteres med holdninger og perspektiver, som ikke svarer til den viden, man selv har. I det følgende skal jeg give to forskellige eksempler på denne problemstilling.

Det første eksempel stammer fra et interview, jeg lavede med en tysk studerende. Interviewet handlede om, hvad kulturforskelle betyder for interaktionen mellem de studerende. Lige præcis denne studerende var af den overbevisning, at det slet ikke giver mening at tale om kulturforskelle blandt unge mennesker i dag; som han blandt andet formulerede det: ,,[...] kultur betyder ikke noget for os. Vores generation er del af den samme kultur. Det kaldes globalisering!“ Som interviewet skred frem, blev det imidlertid tydeligt, at en idé om kultur faktisk var på spil i de interaktioner, han beskrev, og at den især spillede en rolle for hans oplevelser af at blive hørt:

Det er ikke kultur i sig selv, men mere det, andre tror om ens land. Når jeg taler med andre studerende og også med underviserne ... med folk i Danmark, så er det, som 

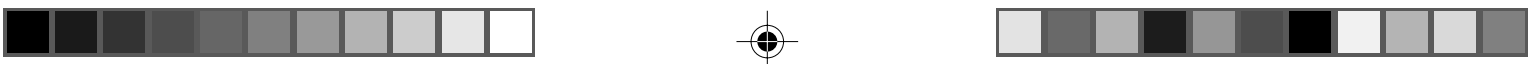

om de ikke kun taler til mig, men til Tyskland ... De taler til det, de tror om Tyskland. [...] Og det er der, jeg føler, at jeg er ansvarlig for mit land. [...] Det, folk tror om ens land, er ofte forkert. Eller deres viden er gammel. Og så er det, at jeg ... at ... [...] jeg føler en solidaritet med mit land ... jeg vil gerne have, at folk får det rigtige indtryk. [...] Jeg føler tit, at folk ikke hører mig. De hører en tysker, og så tænker de på alt det, Tyskland har gjort (Mt1).

Den pågældende studerende vender flere gange i interviewet tilbage til ideen om, at der ikke længere er nogle rigtige kulturforskelle mellem unge mennesker. Men interviewet afspejler også en erkendelse af, at i den konkrete situation kaster folks viden om hans nationalitet og hans lands historie skygger ind over enhver interaktion, han deltager i. Hans nationalitet bliver en slags metakommunikation (Bateson 1972) om værdien af hans udsagn. Dette har ikke kun noget at gøre med, at han er tysk. Adskillige studerende oplever, at der er en slags hierarki mellem de forskellige nationaliteter, og at dette hierarki har betydning for, ,om man er en af dem, der er værd at lytte til“"(Fu1). Meget tyder på, at hierarkiseringen foretages med udgangspunkt i en slags internaliseret mental geografi, som sandsynligvis er del af de studerendes habitus.

Dette er også kernen i næste eksempel, som illustrerer, hvordan en studerende underkendes som autoritet på sit eget land. Eksemplet stammer fra et seminar om minoritetsrettigheder, hvor en dom fra Menneskerettighedsdomstolen, der havde givet den tyrkiske stat medhold i en sag om tørklædeforbud på tyrkiske universiteter, var til debat. Nedenfor gengiver jeg et lille udsnit af en diskussion mellem to danske (Fd8 og Md6) og en tyrkisk (Fty1) studerende på seminaret:

Fd8: Jeg forstår ikke, hvorfor Tyrkiet forbyder tørklæder. Det er deres egen kultur. Fty1: Tørklæder er ikke tyrkisk kultur. Tørklæder er religion. Tyrkiet er et sekulariseret land.

Fd8: Men det er deres kultur ...

Md6: Det er forkert at undertrykke kultur. [...] Jeg forstår ikke dommen. Det er en menneskeret at demonstrere sin religion.

Fty1: Tørklæder er ikke tyrkisk kultur. Jeg forstår ikke, hvorfor europæerne ...

Fd8: I Danmark går alle tyrkere med tørklæde. Det er deres kultur. Så hvorfor forbyder de deres egen kultur?

Som det fremgår af eksemplet, er diskussionen styret af de danske studerendes opfattelse af Tyrkiet og af, hvad der er tyrkisk kultur. Den tyrkiske studerende (Fty1) har svært ved at vinde gehør for sit argument, måske først og fremmest fordi det er ude af trit med den viden om tyrkisk kultur, de danske studerende refererer til. Den ene danske studerende (Fd8) undlader helt at tage stilling til det, den tyrkiske studerende siger, dels ved at flytte fokus i sin argumentation fra Tyrkiet til tyrkere i Danmark og dels ved at ekskludere den tyrkiske studerende 

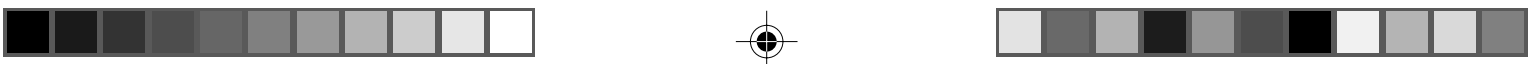

fra tyrkisk kultur. Den danske studerende refererer således til deres kultur og ikke til jeres kultur.

Eksemplet illustrerer både, hvordan forudfattede meninger framer forståelsen af, hvad der foregår, og hvordan det kan være vanskeligt for de studerende at forholde sig til information, der er helt anderledes end den, de har i forvejen. I det konkrete tilfælde bygger de to danske studerende på en viden om tyrkiske forhold, som de primært har fra danske medier og fra deres kendskab til tyrkiske indvandrere i Århus, mens den tyrkiske studerende trækker på sine erfaringer fra en tyrkisk storby og i øvrigt argumenterer ud fra et ønske om, at hendes medstuderende skal få 'det rigtige billede' af Tyrkiet - og i hendes tilfælde er 'det rigtige billede' renset for religion, potentiel kvindeundertrykkelse og konnotationer til orientalisme.

Disse to eksempler giver et indtryk af, hvordan forestillinger om kultur spiller en rolle for interaktionen i det internationale miljø omkring Europastudier. De studerende repræsenterer ikke bare sig selv og deres nationale kulturer, de bliver også fanget $i$ et 'net af betydning', som allerede er spundet (Geertz 1973). Og dette net af betydning har indflydelse på, om deres viden og synspunkter bliver genkendt og anerkendt som viden og synspunkter, der svarer til feltets kulturelle kapital.

Det bemærkelsesværdige i forbindelse med min undersøgelse er, at det er de studerende, der formelt har mest potentiel kapital, der har sværest ved at få deres viden genkendt og anerkendt som faktisk kapital. I en lidt anden sammenhæng har Adrian Blackledge (2001) introduceret begrebet 'forkerte kulturelle kapitaler' om kapitaler, som er akkumuleret i en national sammenhæng, og som viser sig at være svært omsættelige i andre nationale sammenhænge. Dette begreb er relevant i forhold til min undersøgelse, fordi det gør det muligt at fastholde, at de underkendte kapitaler formelt opfylder kriterierne for at være feltets kapital, selv om de ikke umiddelbart genkendes som sådan.

\section{Kulturmødets præmisser}

Når udenlandske studerendes viden og perspektiver kommer til at fremstå som 'forkerte kapitaler', skyldes det ikke kun, at de studerende generelt har forskellige relevanskriterier, og at de forstår hinandens viden i forhold til allerede eksisterende for-forståelser - for det går nemlig alle veje. Når det alligevel er den gruppe, der formelt set har mindst potentiel studierelevant kapital, der kommer til at fremstå som den gruppe, der har mest reel kapital, så skyldes det sandsynligvis, at der er en ulige relation mellem de forskellige grupper af studerende. Jeg vil se nærmere på, hvad det betyder. 

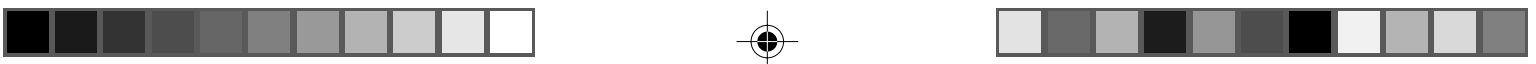

I de fire år, min undersøgelse har strakt sig over, har der konstant været 16-20 forskellige nationaliteter repræsenteret i miljøet omkring Europastudier. Det er imidlertid kun de danske studerende, der fremstår som en gruppe. De fleste andre nationaliteter optræder enkelt- eller parvis. Spørgsmålet om, hvad det betyder og bør betyde, er ofte til debat. Det spørgsmål, som de studerende især kredser om, er spørgsmålet om, hvorvidt de kulturmøder, der finder sted på Europastudier, går ud på, at de udenlandske studerende skal møde dansk kultur, eller hvorvidt de går ud på, at de danske studerende skal gøre plads for udenlandske praksisser. Problemstillingen kan illustreres i forhold til en evigt tilbagevendende diskussion om gruppearbejde, som er en af de arbejdsformer, der anvendes for at give de studerende erfaringer med internationalt samarbejde.

På næsten alle kurser inddeles de studerende i grupper i forhold til en række potentielt interessante forskelle: $\mathrm{k} ø$, alder, nationalitet, sprog, tidligere uddannelse m.v. Grupperne opfordres til at reflektere over, hvilke forskelle, de mener, gør en forskel, og hvilke forskelle der kan gøres til ressourcer. Der lægges således ikke op til, at interkulturel kompetence nødvendigvis er en kompetence til at samarbejde med nationalt forskellige mennesker, men at det er en kompetence, der involverer evnen til at gøre forskelle til en ressource.

Gruppearbejde er en omdiskuteret pædagogisk metode. Og en af de problemstillinger, der jævnligt er oppe at vende, er spørgsmålet om, hvorvidt gruppearbejde repræsenterer et møde med dansk kultur, eller hvorvidt det er et kulturneutralt middel i den interkulturelle interaktion. Påfaldende mange danske studerende har den opfattelse, at gruppearbejde er en særlig dansk specialitet. Som en dansk studerende udtrykte det $i$ en diskussion af formålet: „Er det ikke det, Anne Knudsen siger? Hun siger, at danskere har siddet i rundkreds og arbejdet i grupper, siden de var små, og det giver os en særlig måde at gøre tingene på“ (Md12). Denne særlige måde at gøre tingene på betragter mange af de danske studerende som noget, udenlandske studerende skal socialiseres ind i, og det skaber en række problemer og konflikter. Danske studerende oplever, at udenlandske studerende ikke rigtig kan eller vil lære denne særlige danske kulturelle samarbejdsform. De oplever det også som et tyngende ansvar, som uddannelsesinstitutionen lidt urimeligt tørrer af på dem. Følgende to citater stammer fra danske studerendes vurderinger af gruppearbejde:

Fd9: Som dansker kommer man let til at være den, der skal lede det hele. Man skal sætte de andre i gang og sørge for, at tingene fungerer. Så man lærer ikke selv så meget ved at deltage i gruppearbejde her på stedet.

Md10: Det er heller ikke rimeligt at lægge det over på os studerende at undervise de udenlandske studerende i, hvordan man gør tingene. Det må være lærernes opgave at sørge for, de studerende kan det, de skal [...]. 

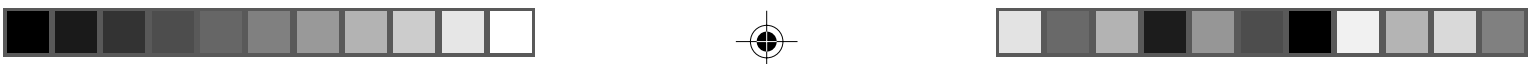

Disse danske studerende fremstiller således gruppearbejde som en art kulturel mission. Eller måske snarere som en del af den kultur, de udenlandske studerende skal møde, mens de er i Danmark. Modsat fremstiller udenlandske studerende gruppearbejdet som en forudsætning for snarere end en ingrediens i kulturmødet. Som en udenlandsk studerende sagde i en klassediskussion om, hvilke forskelle der er vigtige i forhold til gruppearbejde: ,Jeg tror virkelig ikke, det var en dansker, der opfandt teamwork. Det er jo latterligt!“ (Ft2).

Udenlandske studerende fremstiller ofte gruppearbejde som noget, der forhindrer ligeværdig interaktion. Som en anden udenlandsk studerende udtrykte det: „I alle de grupper, jeg har været med i ... og det er ikke kun her på Europastudier, det er også andre steder ... de danske studerende foreslår, at vi opdeler arbejdet. Så tager vi en opgave hver og laver den selv. [...] På den måde kommer vi ikke til at arbejde sammen“( Fj3).

Der er flere ting på spil i diskussionen om gruppearbejde. For det første er de studerende ikke enige om, hvorvidt det handler om, at de udenlandske studerende skal møde dansk kultur, eller at de danske studerende skal møde 'udenlandske' praksisser. I den forstand er ideen om kulturmøde på spil. For det andet afspejler diskussionen den deling, som flertallet af de studerende i praksis orienterer deres forståelser af interkulturel interaktion i forhold til, nemlig en deling mellem danske og udenlandske studerende. Som en af de studerende i en anden forbindelse formulerede det, vil der altid være et hjemmebanehold, og dette hjemmebanehold vil altid have hjemmebanefordel (Davidis 2008). I den forstand oplever de studerende ikke, at kulturmødet på Europastudier giver plads for kulturel forskellighed. I stedet oplever de, at det bygger på en ulige relation.

\section{Erasmus Montanus på hjemmebane}

Ideen om, at interaktionen mellem de studerende først og fremmest er baseret på en ulige relation mellem et udebanehold og et hjemmebanehold, går igen, når de studerende reflekterer over undervisningen. Både danske og udenlandske studerende er overvejende enige om, at hjemmebaneholdet har en række fordele, når det gælder om at få udbytte af undervisningen. Danske studerende relaterer ofte fordelene til hjemmebanen i sig selv - „,det er jo klart, at det er lettere for os. Vi kender jo den måde tingene foregår på“" (Fd6) - selv om en del af dem også er tilbøjelige til at mene, at fordelene skyldes, at de simpelthen er bedre uddannet. De udenlandske studerende fremhæver ofte måden, det faglige stof formidles på, når de skal forklare, hvad hjemmebanefordelen betyder - ,underviserne bruger ofte danske eksempler, når de vil forklare noget, og det gør det sværere for os [udenlandske studerende] at deltage“" (Fr2). 
Men det er faktisk ikke helt så enkelt, at undervisningen - og underviserne bare favoriserer de danske studerende. Det er heller ikke så enkelt, at de danske studerende nødvendigvis klarer sig bedre eller deltager mere, end de udenlandske studerende gør. I stedet er der noget, der tyder på, at der i relationen mellem brugen af lokalt forankret kontekstviden i undervisningen og de studerendes fortolkninger af, hvad det indebærer, skabes og opretholdes en illusion om en hjemmebane og en hjemmebanefordel. Det vil jeg illustrere med et eksempel fra en undervisningssituation, som viser, hvordan brugen af lokalt forankret kontekstviden kan være med til at skabe en illusion om, at danske studerende har hjemmebanefordel. Jeg fremlægger først mine noter fra undervisningen:

Lærer: Det er det man kalder [pause] ... kender I alle Erasmus Montanus? Har I hørt om ham?

[Pause. Tre studerende (ud af 20, 11 danske og 9 udenlandske) rækker hånden op, en udenlandsk (F13) og to danske (Fd14, Md9)]

Lærer (peger på Fl3): Ja?

Fl3: Erasmus af Rotterdam?

Lærer: Nej, det er ikke ham [pause] ... andre? (peger på Fd14): Ja?

Fd14: Det er Holberg ...

Lærer: Ja, det er Holberg, der har skrevet om Erasmus Montanus. Hvad var der med ham?

Fd14: Han var ude at rejse [pause] ... Jeg ved ikke, om han tog til Rotterdam ...? Lærer: Nej... nej. Andre bud? [peger på Md9]. Ved du det?

Md9: Det, du er ude efter, er at ... mor ... at lille mor er en sten. At Erasmus rejste til ... var det ikke København? ... Og da han kom hjem, beviste han at ... lille mor ... altså mor lille - hvordan siger man det på engelsk? - var en sten.

Lærer: Ja, det vi er interesserede i, er præmisserne for argumentationen [...].

Eksemplet er taget fra en undervisningssituation, hvor man er i gang med at diskutere opbygningen af en akademisk argumentation. Jeg har valgt det, fordi det er prototypisk for en situation, de fleste undervisere med jævne mellemrum står i. De skal eksemplificere et argument eller en pointe og bruger et eksempel, som de i situationen bliver opmærksom på ikke kan forudsættes at være alment kendt. Derfor giver de sig til at forklare eksemplet, hvorved fokus flyttes fra 'tekst til kontekst'. På den måde sker der en reframing af undervisningssituationen (fx Bateson 1991:118), således at eksemplets kulturelle konnotationer kommer i fokus, og undervisningen får karakter af en slags indføring i dansk kultur.

Det er i situationer som disse, at udenlandske studerende føler, at undervisningen favoriserer de danske studerende og giver dem en hjemmebanefordel. Men faktisk er det ikke kun de udenlandske studerende, der ikke forstår eksemplet. Som man fx kan se af citatet, virker det ikke, som om den danske studerende (Fd14) er klar over, hvad det er ved Holbergs Erasmus Montanus, der kunne 

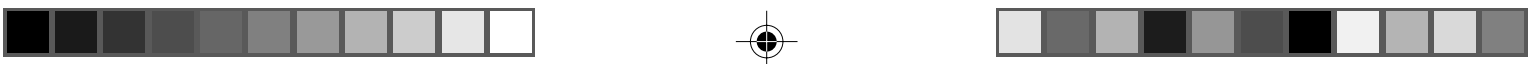

være relevant i sammenhængen. Og faktisk er det kun de (relativt få) danske studerende, der har forholdsvis meget kulturel kapital, der ser ud til at have fordel af undervisernes brug af lokalt forankret kontekstviden. Ved at gå ud fra, at alle danske studerende har hjemmebanefordel i situationer som den pågældende, gøres en stor del af de danske studerende til medejere af en kulturel kapital, de faktisk ikke besidder. I den forstand forveksles uddannelsessystemets klassespecifikke kapital med de studerendes nationale kapital.

\section{Når kultur kommer i vejen}

Internationalisering er et af tidens uddannelsespolitiske buzz-words. Det spiller en rolle for den nationale og internationale konkurrence mellem universiteter, og det spiller en rolle i de mere idealistiske diskurser om fredelig sameksistens. I forbindelse med europæisk integration fx, gør man et fors $\emptyset \mathrm{g}$ på at fremme studentermobilitet ud fra en forestilling om, at det kan være med til at nedbryde fordomme og snæversyn og gøre forskel til en fordel (se fx www.interculturaldialogue 2008.eu).

Internationalisering gennem studentermobilitet er baseret på to forudsætninger. Den ene er, at man relativt uproblematisk kan flytte 'skolastisk kapital' fra en national uddannelsessammenhæng til en anden. Den anden er, at man kan skabe miljøer ved nationale universiteter, hvor indenlandske og udenlandske studerende kan bidrage på lige fod. Disse to antagelser er interessante i forhold til diskussioner om kulturmøder, fordi de indebærer en idé om interkulturel kompatibilitet inden for de videregående uddannelser. I denne artikel diskuterer jeg dem i forhold til en undersøgelse, jeg har foretaget på en international uddannelse i Danmark. Denne undersøgelse har dels bestået i en udredning af de studerendes kulturelle kapitaler og dels i en undersøgelse af deres opfattelser af kulturforskelles betydning. Undersøgelsen henleder opmærksomheden på fire forhold, som især er interessante i forhold til forståelsen af betydningen af kulturmøder i forbindelse med internationalisering af videregående uddannelser.

Det første forhold vedrører de studerendes kulturelle kapitaler. Hvis man definerer kulturmøder som møder mellem mennesker med forskellige mængder og sammensætninger af kulturelle kapitaler (jf. Christensen 1994), er det relevant at forholde sig til, hvor meget eller hvor lidt kulturel kapital agenterne i kulturmødet har. Min undersøgelse har vist, at der både er nogle store ligheder og nogle markante forskelle mellem de studerende, der optages på Europastudier. En stor del af de studerende er førstegenerationsstuderende, hvilket i sig selv er interessant. Men i forhold til en diskussion af kulturmøder er det måske mere interessant, at uddannelsen både tiltrækker studerende med en meget stor og 

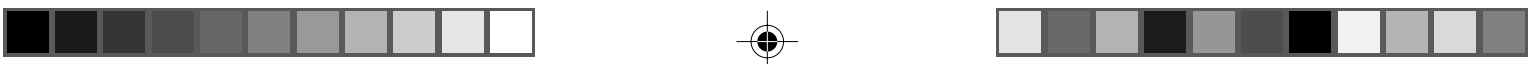

med en meget lille potentiel kapital. Min undersøgelse viser, at det især er udenlandske studerende, der har meget potentiel kapital. Den viser også, at der er et relativt sammenfald mellem nationalt/regionalt tilhørsforhold og mængden af potentiel kapital, hvilket i praksis kan få det til at se ud, som om forskelle er nationalt/regionalt snarere end socialt afledte.

Det andet forhold, min undersøgelse belyser, vedrører den faktiske anerkendelse af de studerendes kapitaler. Der er nemlig noget, der tyder på, at de studerende har vanskeligt ved at genkende og anerkende hinandens viden som relevant og interessant, hvorfor de studerende, der potentielt har mest kulturel kapital, indimellem kommer til at fremstå som dem med mindst kulturel kapital. I undersøgelsen forklarer jeg dette med reference til forskellene i de studerendes kontekstviden og med reference til de for-forståelser, som de studerende klassificerer sig selv og hinanden i forhold til. Forskellene i kontekstviden gør det vanskeligt for de studerende at genkende hinandens viden og at anerkende hinandens relevanskriterier, hvorfor viden ofte bliver affejet som uinteressant. Og klassifikation i forhold til for-forståelser gør det vanskeligt for dem at se ud over stereotype forestillinger om, hvordan denne eller hin nations mennesker er.

Det tredje forhold, min undersøgelse har belyst, er spørgsmålet om, hvordan de studerende selv opfatter muligheder og begrænsninger i et internationalt studiemiljø. Denne del af undersøgelsen har vist, at de studerende først og fremmest opfatter miljøet som bestående af et udebanehold og et hjemmebanehold. Denne opfattelse har sandsynligvis afsæt i det forhold, at der er meget store forskelle i den numeriske repræsentation af forskellige nationaliteter, hvorfor den danske gruppe kommer til at fremstå som meget dominerende. Men den har også afsæt i en grundlæggende uenighed om, hvad kulturmødet i grunden går ud på. De fleste danske studerende og en del af de danske undervisere giver enten i ord eller handling udtryk for, at kulturmødet først og fremmest er de udenlandske studerendes møde med dansk kultur, mens de fleste udenlandske studerende giver udtryk for en idé om, at kulturmødet bør give alle 'kulturer' mulighed for at mødes.

Det sidste forhold, min undersøgelse bidrager til at belyse, er spørgsmålet om, hvad hjemmebanefordelen faktisk betyder, når de studerende forholder sig til undervisningen og til deres egne og andres muligheder for at få udbytte af den. I den forbindelse argumenterer jeg for, at der i højere grad er tale om en illusion om en hjemmebanefordel, end der er tale om en reel fordel for alle danske studerende. Mens det nemlig er korrekt, at undervisere meget ofte trækker på lokalt forankrede eksempler, når de skal forklare faglige problemstillinger, og dermed faktisk gør det vanskeligt for en del af de udenlandske studerende at følge opbygningen af faglige argumentationer, er det ikke korrekt, at dette automatisk giver 
alle danske studerende en fordel. Tværtimod forfordeles alle de studerende, der mangler relevant kulturel kapital, hvad enten denne mangel skyldes forskelle i kontekstviden eller skyldes, at de studerende ikke har særlig meget kulturel kapital til at begynde med. Det er kun, hvis man alene fokuserer på nationale forskelle og ikke også fokuserer på sociale forskelle, at man kan opretholde illusionen om en national hjemmebane.

På den baggrund viser min undersøgelse, at internationalisering faktisk involverer en række udfordringer, og at man ikke bare kan gå ud fra, at kulturmøder i uddannelsessektoren er baseret på interkulturel kompatibilitet. Tværtimod er der noget, der tyder på, at 'kultur' kommer i vejen, både hvis man definerer den som kulturel kapital, og hvis man forholder sig til den, som var den lig med de forestillinger om kultur, som de studerende orienterer sig i forhold til.

\section{Noter}

1. Tak til Ann-Christina Lauring Knudsen, Janne Bleeg Jensen, Kirsten Gomard og Hanne Veber for kommentarer til tidligere udkast af denne artikel. Tak også til en meget tålmodig tidsskriftsredaktion.

2. Undersøgelsen er en del af et projekt, jeg har lavet for Akademiet for Migrationsstudier i Danmark om EU's kulturpolitiske visioner vedrørende migration og bevægelse. Projektet blev finansieret af de daværende humanistiske og samfundsvidenskabelige forskningsråd.

3. I 2004, 2005 og 2006 optog Europastudier et større antal kinesiske studerende. Traditionelt har der også årligt været mange ansøgninger fra afrikanske studerende, men kun få af dem er nogensinde dukket op, og indtil videre har ingen af dem gennemført uddannelsen. Det forventes at antallet af kinesiske (og ikke-europæiske) ansøgere vil falde, efter at danske universiteter har indført tuition fees for ikke-europæiske studerende.

4. Studerende, der citeres i artiklen, identificeres i forhold til køn, nationalitet og et nummer, der refererer til mine optegnelser.

5. Undersøgelsen blev gennemført af undertegnede og to studerende, Nanna Juul Jensen og Signe Christiansen.

6. Citaterne er her gengivet på dansk efter spørgeskemaundersøgelsen fra 2004. Samtlige citater er oversat til dansk i forbindelse med skrivningen af denne artikel.

7. Det er lidt forskelligt fra årgang til årgang, hvordan de forskellige kategorier fordeler sig. Gennemsnitlig er $35 \%$ af de studerende danske studerende, der i højere grad har fravalgt deres tidligere uddannelse, end de har tilvalgt Europastudier. Cirka $30 \%$ har valgt uddannelsen, fordi de håber at forbedre deres karrieremuligheder hjemme, $20 \%$ er reelt interesserede $\mathrm{i}$ en international uddannelse i Europastudier, og $15 \%$ er i Århus af andre grunde.

8. Det svarer til $91 \%$ af samtlige de kandidatstuderende, der i løbet af undersøgelsesperioden har gennemført mere end et semester af uddannelsen, samt de udvekslings- og suppleringsstuderende, der deltog i kurset „Culture and Cooperation“ på Europastudier i foråret 2006, og som på mange måder inspirerede mit arbejde. 
9. ‘Østeuropæisk' refererer her til studerende fra Baltikum, Rusland, Central- og Østeuropa samt Balkan.

10. Kategorien 'ikke-europæiske, ikke-vestlige studerende' udgøres primært af kinesiske studerende, men i tidens løb har der også været enkelte afrikanske, indiske og asiatiske studerende.

11. Disse data er ikke fremlagt her.

12. Opdelingen i forskellige former for viden er selvfølgelig fiktiv, men der er dog tale om en fiktion, der dels har afsæt i en konventionel distinktion (fx mellem klassisk musik og populær musik, teaterforestillinger og tv-serier, litteratur og samfundsteori) og dels i en analytisk evident distinktion mellem god og dårlig smag. Denne distinktion reflekteres fx i de studerendes besvarelser af spørgeskemaerne, hvor eksempelvis et ofte påfaldende godt kendskab til amerikanske tv-serier følges af kommentarer som „crap American teen soap“, „horrible day time television“, „really stinky so-called reality show“ etc. På samme måde følges et i øvrigt langt mindre udbredt kendskab til 'finkultur' ofte af kommentarer. Spørgeskemaet rummer fx to stavefejl - Kandinski er stavet Kadinski, og Dostojevskij er stavet Dostovjevski - og de fleste af de studerende, der kender Kandinski og Dostojevskij, har ulejliget sig med at rette fejlene. En enkelt noterede oven i købet at „,it’s Kandinski, you stupid!“.

13. Jeg har fem gange i undersøgelsesperioden optaget min egen undervisning for at få indblik i, hvad det er for en viden, jeg selv trækker på i min kommunikation med studerende, og hvad det er for eksempler, jeg tyr til, når jeg skal forklare problemstillinger og svare på spørgsmål. Jeg har herudover undervist en række forløb sammen med forskellige kollegaer og har i den forbindelse fået feedback på undervisningsform og -metode.

\section{Litteratur}

Baumgratz, Gisela \& Gisela Shaw

1993 Mobility in Higher Education: Cross-Cultural Communication Issues. European Journal of Education 28(3):327-38

Bateson, Gregory

1972 Steps to an Ecology of Mind. New York: Ballentine Books.

1991 And og natur - en nødvendig enhed. København: Rosinante/Munksgaard.

Blackledge, Adrian

2001 The Wrong Sort of Capital? Bangladeshi Women and Their Children's Schooling in Birmingham U.K International Journal of Bilingualism 5(3):345-69.

Bourdieu, Pierre

1974 The School as a Conservative Force: Scholastic and Cultural Inequalities. I: J.

Eggleston (ed.): Contemporary Research in the Sociology of Education. London: Methuen.

1984 Distinction: A Social Critique of the Judgement of Taste. Cambridge, MA: Harvard University Press.

1986 The Forms of Capital. I: J.G. Richardson (ed.): Handbook of Theory and Research for the Sociology of Education. Pp. 241-58. New York: Greenwood Press.

1988 Homo Academicus. Cambridge: Polity Press.

1990 In Other Words: Essays Towards a Reflexive Sociology. Cambridge: Polity Press.

1993 Sociology in Question. London: Sage Publications.

2003 Participant Objectivation: The Huxley Medal Lecture. Journal of the Royal Anthropological Institute 9(2):281-94. 
Bourdieu, Pierre \& Jean Claude Passeron

1979 The Inheritors: French Students and Their Relation to Culture. Chicago: Chicago University Press.

1990 Reproduction in Education, Society and Culture. London: Sage Publication \& Theory, Culture, Society.

Broady, Donald

2001 What is Cultural Capital? Comments on Lennart Rosenlund's Social Structure and Change. Sociologisk Arbok 2:45-59.

Byram, Michael

1990 Teachers and Pupils: The Significance of Cultural Identity. I: Byram \& Lehman (eds.): Bicultural and Trilingual Education. Clevedon: Multilingual Matters Ltd.

Carroll, Jude \& Janette Ryan

2005 Teaching International Students: Improving. Learning For All. London: Routledge.

Christensen, John Gulløv

1994 Sprog og kultur i europæisk integration. I: John Liep \& Karen Fog Olwig (red.): Komplekse liv. Kulturel mangfoldighed i Danmark. København: Akademisk Forlag.

Davidis, Yvonne

2007 European Identity Under Construction? An Analysis of How European Studies Students Make Sense of Themselves and Europe. MA Thesis. Århus Universitet.

Geertz, Clifford

1973 The Interpretation of Cultures: Selected Essays. New York: Basic Books.

Goffman, Erving

1959 The Presentation of Self in Everyday Life. New York: Doubleday.

Hofstede, Geert

1986 Cultural Differences in Teaching and Learning. International Journal of Intercultural Relations 10(3):301-20.

Knight, Jane \& Hans De Wit

1995 Strategies for the Internationalisation of Higher Education. A Comparative Study of Australia, Canada, Europe and the United States of America. Amsterdam: EAIE Secretariat.

Lamont, Michele \& Annette Lareau

$1988 \quad$ Cultural Capital: Allusions, Gaps and Glissandos in Recent Theoretical Developments. Sociological Theory 6(2):153-68.

Lareau, Annette \& Eliot B.Weininger

2003 Cultural Capital in Educational Research: A Critical Assessment. Theory \& Society 32:567-606.

Luiten-Lub, Anneke et al.

2005 On Cooperation and Competition. A Comparative Analysis of National Policies for Internationalisation of Higher Education in Seven Western European Countries. Journal of Studies in International Education 9(2):147-63. 
Naidoo, Vikash

2005 Bridging the Gap between Anecdotal and Empirical Evidence in the International Education Market: Insights from the US and UK. http://www.idp.com/aiec/ program/Naidoo,\%20Vikash.pdf.

Ollikainen, Aaro

1996 Conflicts, Status Competition, and Different Rationales for Mobility: A Finnish Experience on Some Neglected Issues in International Education. Frontiers. The Interdisciplinary Journal of Study Abroad 2 [online].

Otten, Matthias

2003 Intercultural Learning and Diversity in Higher Education. Journal of Studies in International Education 7(1):5-11.

Peterson, Richard A.

1992 Understanding Audience Segmentation: From Elite and Mass to Omnivore and Univore. Poetics 21:243-58.

Sing, Parlo \& Catherine Doherty

2004 Global Cultural Flows and Pedagogic Dilemmas: Teaching in the Global

University Contact Zone. Tesol Quarterly 38(1):9-42.

Teichler, Ulrich

2004 Temporary Study Abroad: The life of ERASMUS Students. European Journal of Education 39(4):395-408.

van Eijck, Koen

2001 Social Differentiation in Musical Taste Patterns. Social Forces 79(3):1163-84.

Vickers, Phil \& Bahram Bekhradnia

2007 The Economic Costs and Benefits from International Students. Higher Education Policy Institute. http://www.hepi.ac.uk/pubdetail.asp?ID=236\&DOC=reports.

Volet, Simone \& G. Ang

1998 Culturally Mixed Groups on International Campuses: An Opportunity for Intercultural Learning. Higher Education Research and Development 17(1):5-23.

\section{Websites}

European Commission

http://ec.europa.eu/culture/eac/dialogue/year2008/year2008_en.html (besøgt januar 2008).

http://www.interculturaldialogue2008.eu (besøgt januar 2008).

Europa-Kommissionen

http://www.europa-kommissionen.dk/eu-politik/noegleomraader/udd_kultur_info/ interkulturel-dialog/lancering/ (besøgt januar 2008).

Department of European Studies

http://www.iho.au.dk/en/es/department/presentation (besøgt september 2007).

http://www.iho.au.dk/en/es/studies/intro (besøgt september 2007). 